\title{
PERMEABILITY VARIATION IN FLUVIAL SANDSTONES OF THE MARIZAL FORMATION (APTIAN, TUCANO BASIN, NE BRAZIL)
}

\author{
Kíron R. Hashimoto*, Bernardo T. Freitas.
}

\begin{abstract}
This work aims at the study of the permeability distribution in relatively homogeneous fluvial sandstones, analogues for underground reservoirs of water and hidrocarbons. Outcrops of ancient sedimentary deposits mapped as the Banzaê Member of the Aptian Marizal Formation, fluvial in origin, in the Tucano Basin, NE-Bahia, were analysed with emphasis in petrophisical data acquired in the field using a portable handheld air permeameter (Tiny Perm II) from deposits previously interpreted as compound bar and abandoned channel deposits. The analyzed data allowed the recognition of distintct permeability distributions in architectural elements previously assumed as sedimentologicaly and petrographicaly indistinguishable. A third dataset could not be reconcilied with the above previous interpretations, pointing to the need of further detailment of those deposits. However, the general distribution of permeability values in the studied context are covariant with primary sedimentological properties, highlighting the relationship between underground reservoir origin and its petrophisical properties.
\end{abstract}

\section{Key words:}

Geology, Geosciences, Sedimentology.

\section{Introduction}

This study adresses a sedimental sucession analogue to fluvial originated underground reservoirs characterized by an apparent monotony due to the prevalence of cross strata sandstones with a very low mud to sand ratio. The aforementioned deposits belong to the Banzaê Member of the Marizal Formation (Freitas et al., 2017) and due to its monotony were primarily characterized considering the distribution of cross strata sets thickness and its depositional surfaces orientations (Freitas, 2014; Almeida et al., 2016).

This primary characterization (Freitas, 2014) allowed the distinction between fluvial deposits originated in different subenvironments such as compound bars and channel fills (sensu Bridge, 2003) and the verification of the existence of a relation between the sedimentological parameters evaluated, such as sets and cosets thickness, and petrophisical properties such as permeability. This way, the permeability values distribution, obtained via the handheld permeameter (Tiny Perm II) in the same previously studied and interpreted deposits characterized as compound bars or channel fills, were analyzed..

\section{Results and Discussion}

The permeability measurements and facies analysis were performed on three outcrops named Su 1, Su 2 and Su 3. Su 2 and Su 3 are characterized as compound bar and channel fill deposits respectively and Su 1, that lies within a few hundred meters from the others, was not previously characterized.

The permeability values were determined through two calibration curves. Four datasets were selected for the study: all the points in all outcrops, all the points made of middle to thick sandstones in all outcrops (Image 1), all the points in the lateral correlated sections in all outcrops and lastly, all the points in the lateral correlated sections made of middle to thick sandstones in all outcrops. The obtained values for each dataset, through either methods, were boxploted side by side. The majority of statistics parameters in all datasets, through both methods, followed a pattern illustrated by the following boxplot.

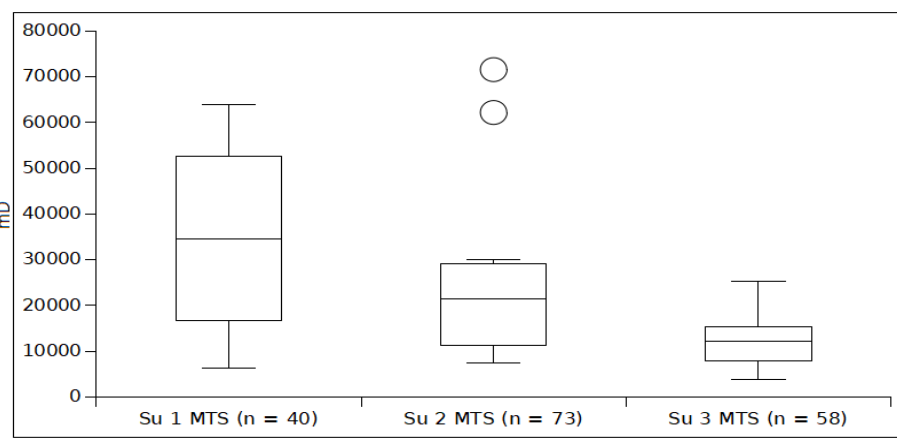

Image 1. Middle to thick sandstones points in all outcrops permeability boxplot. Units are in milliDarcy.

\section{Conclusions}

Regarding Su 2 and Su 3, all datasets boxplots points towards channel fill deposits having lower permeability values distributions than that of compound bar deposits. The last two datasets had values distributed in higher ranges which suggests granulometry as a significant control factor for permeability Nevertheless, considering Su 2's and Su 3's components in the last two datasets, covariance between sets and cosets thickness and permeability is observed, which suggests that there are significant petrophisical diferences between compound bars and channel fills.

Almeida, R.P. et al, 2016 b. Reconstructing fluvial bar surfaces from compound cross-strata and the interpretation of bar accretion direction in large river deposits. Sedimentology, 63, 609-628.

Bridge, J. S., 2003, Rivers and flood plains: Forms, processes and sedimentary record: Oxford, Blackwell, $491 \mathrm{p}$.

Freitas B. T., 2014. A Formação Marizal (Aptiano) na bacia do Tucano (BA) contribuições à análise da arquitetura de depósitos fluviais e implicações paleobiogeográficas. Tese de doutorado, Universidade de São Paulo, Brasil, $175 \mathrm{pp}$.

Freitas B.T. et al, 2017. Aptian sedimentation in the Recôncavo-TucanoJatobá Rift System and its tectonic and paleogeographic significance. Journal of South American Earth Sciences, 80, 460-481. 